\title{
Middle Triassic trachytic lava flows associated with coeval dyke swarm in the North Patagonian Massif: A postorogenic magmatism related to extensional collapse of the Gondwanide orogen
}

\author{
Santiago N. González ${ }^{\text {a, }}$, Gerson A. Greco a , Ana M. Sato ${ }^{\text {b }}$, Eduardo J. Llambías ${ }^{\text {b }}$, \\ Miguel A.S. Basei ${ }^{\mathrm{c}}$, Pablo D. González ${ }^{\mathrm{a}}$, Pablo E. Díaz ${ }^{\mathrm{d}}$ \\ a Instituto de Investigación en Paleobiología y Geología (CONICET-UNRN), Av. Julio A. Roca 1242, R 8332 EXZ General Roca (Río Negro), Argentina \\ ${ }^{\mathrm{b}}$ Centro de Investigaciones Geológicas (CONICET-UNLP), Calle 1 N ${ }^{\circ} 644$, B 1900 TAC La Plata (Buenos Aires), Argentina

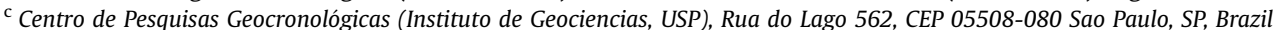 \\ ${ }^{\mathrm{d}}$ Facultad de Ciencias exactas y Naturales (Dpto. Geología) - UNLPam, Campo de enseñanza, Ruta 35, km 334, Santa Rosa, La Pampa.Pabellón de Geología, \\ Argentina
}

\section{A R T I C L E I N F O}

\section{Article history:}

Received 27 September 2016

Received in revised form

17 February 2017

Accepted 19 February 2017

Available online 21 February 2017

\section{Introduction}

The Marifil Volcanic Complex is an extensive magmatic and pyroclastic unit included in the Chon Aike Siliceous Large Igneous Province (SLIP) (Malvicini and Llambías, 1974; Cortés, 1981; Pankhurst et al., 1998). It was first considered as the Jurassic thick rhyolitic plateau overlaying mesosilicic lava flows (Malvicini and Llambías, 1974). Cortés (1981) extended this unit including the underlying possibly Triassic mesosilicic rocks, and the epiclastic succession of the Puesto Piris Formation (Núñez et al., 1975). Modern works increased the quality and amount of the geochronological data of the Marfil volcanism using $\mathrm{Rb}-\mathrm{Sr}$ and Ar-Ar methods. Rapela and Pankhurst (1993), Pankhurst and Rapela (1995), Pankhurst et al. (1998, 2000) and Féraud et al. (1999) establish a lapse between 188 and 165 Ma for the eruption of the Marifil Volcanic Complex. Still, there are some Middle Triassic K-Ar ages from the Marifil volcanism which differ from the Jurassic Ar-Ar and Rb-Sr data (Fig. 1; Vallés, 1978; Cortés, 1981; Genovese, 1995). A U-Pb zircon crystallization age of a mesosilicic dyke swarm opened the possibility for a major

\footnotetext{
* Corresponding author. Instituto de Investigación en Paleobiología y Geología (Consejo Nacional de Investigaciones Científicas y Técnicas - Universidad Nacional de Río Negro), Av. Julio A. Roca 1242. R 8332 EXZ. General Roca (Río Negro). Argentina.

E-mail address: sgonzalez@unrn.edu.ar (S.N. González).
}

Triassic magmatic process (González et al., 2014b, 2016).

The dyke swarm has been linked to a postorogenic extension related to changes in the subduction along the southwestern margin of Gondwana (Uliana et al., 1985; González. et al., 2014b, 2016). On the contrary, the origin of the rhyolitic plateau of the Marifil Volcanic Complex has been associated with the Karoo within-plate magmatic event (Pankhurst et al., 1998, 2000; Riley et al., 2001).

The mesosilicic rocks at the base of Marfifil Volcanic Complex are trachytes (see section 3.3). As they cover Permian granitoids and have a similar composition to the Triassic dyke swarm is possible that the Marifil Volcanic Complex comprise two different geotectonic and magmatic processes.

A section near Arroyo Ventana where the Monasa volcanic rocks are well-exposed was selected to investigate the trachytic base of the Marifil Volcanic Complex (Fig. 1; Franchi et al., 2001). A field description and mapping of the outcropping units and a petrographic characterization of the mesosilicic rocks were performed. Additionally, a geochemical analysis and a geochronological study were made over a trachyte from a lava flow. The characterization of the mesosilicic rocks as well as the obtained $\mathrm{U}-\mathrm{Pb}$ zircon age allow us to separate the trachytes from the rhyolites. We extend the Monasa Formation to include Triassic mesosilicic rocks and separate it from the Marifil Volcanic Complex. Additionally we focus on other areas of the North Patagonian Massif where temporally equivalent rocks crop out and present similar stratigraphic relations. The presence of similar rocks, temporally equivalent and with analogous stratigraphic relations allow us to proposed the existence of a magmatic process widespread in the North Patagonian Massif possible associated to a Triassic postorogenic extensional regime.

\section{Geologic setting}

The studied area is close to Arroyo Ventana $\left(41^{\circ} 38^{\prime} 41.10^{\prime \prime} \mathrm{S} ; 66^{\circ}\right.$ 


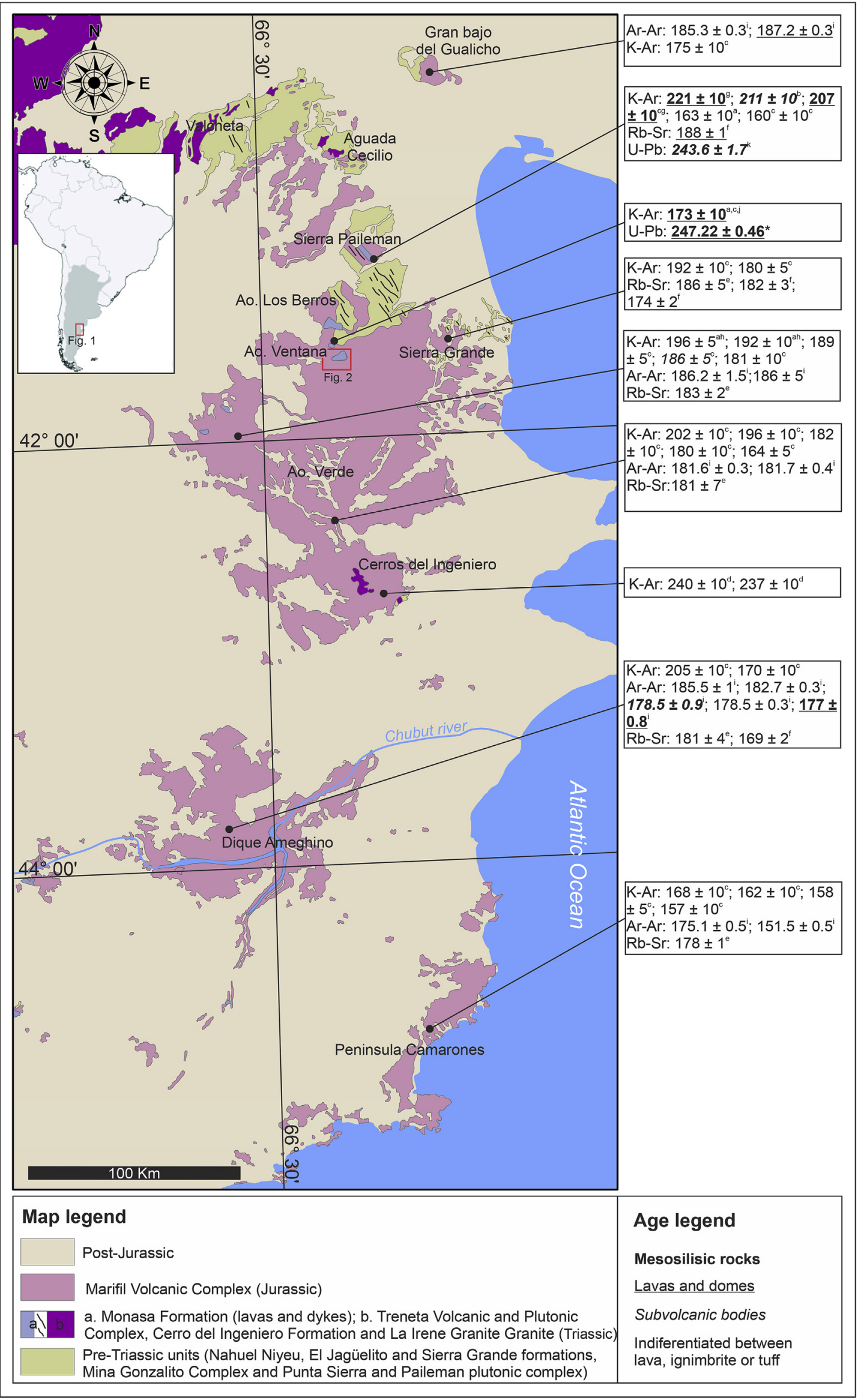

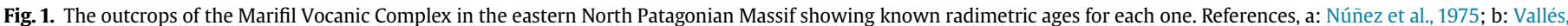

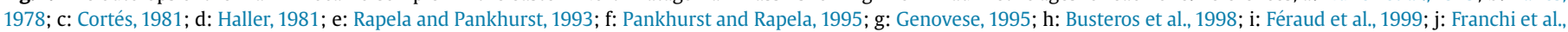
2001; k: González et al., 2014b; * this work. Map simplified from Busteros et al. (1998), Caminos (2001), Franchi et al. (2001), Haller (1981), Lizuaín et al. (1995). 
$\left.0^{\prime} 59.24^{\prime \prime} \mathrm{W}\right), 60 \mathrm{~km}$ west from Sierra Grande in the eastern North Patagonian Massif (Fig. 1). The geology of the area was compiled and summarized by Busteros et al. (1998) and Franchi et al. (2001).

The basement of the area is composed of Early Palaeozoic igneous and metamorphic rocks. The Mina Gonzalito Complex and El Jagüelito Formation metamorphic rocks (Ramos, 1975; Giacosa, 1987) are intruded by the Early-to-Middle Ordovician granitoids of the Punta Sierra Plutonic Complex (Busteros et al., 1998). The metamorphic units comprise metasedimentary rocks interbedded with igneous mafic and felsic rocks (de Alba, 1964; Ramos, 1975; Giacosa, 1987; González. et al., 2008a, 2008b, 2011a, 2013, 2014a). The sedimentation of the protoliths as well as the crystallization age of the pretectonic igneous rocks have been proposed as Cambrian. This age is based on fossils, detrital zircon ages and magmatic zircon ages (González et al., 2002, 2011b, 2013; Pankhurst et al., 2006; Naipauer et al., 2010; Varela et al., 2011; Greco et al., 2014).

The Permian Pailemán Plutonic Complex intrudes the igneous and metamorphic basement rocks (Giacosa, 1993). This unit comprises several plutons with crystallization ages between 291 and $261 \mathrm{Ma}$ (Grecco et al., 1994; Busteros et al., 1998; Varela et al., 2008; Grecco and Gregori, 2011; García et al., 2014). Petrographical and geochemical features of the plutons suggest affinities with calcalkaline series related to a subduction margin (Giacosa, 1993; Grecco et al., 1994; Busteros et al., 1998; García et al., 2014). The Permian plutonism in the North Patagonian Massif has been related to the Gondwanide magmatic arc (Rapela and Llambías, 1985; Giacosa, 1993; Llambías and Sato, 2011; Sato et al., 2015). The Permian intrusive rocks form a NW-SE-trending magmatic arc related to a NE-SW compressive regime in the northern Patagonia (Ramos, 1984; Giacosa, 2001; Llambías et al., 2002; von Gosen, 2002, 2009; González et al., 2014b, 2016; Greco et al., 2015).

Ductile and fragile-ductile to fragile shear zones affect the mentioned units (Giacosa, 2001; von Gosen, 2002). These shear zones are considered as deformational structures of the Permian Gondwanide orogeny (Giacosa, 2001; von Gosen, 2002). Major faults, $\mathrm{km}$-scale folds and brittle-ductile microstructures affecting a Siluro-Devonian sedimentary cover in Sierra Grande area have also been considered as deformational structures of the Gondwanide orogeny (Japas, 2001; von Gosen, 2002).

A NW-SE trachytic dyke swarm cuts the brittle-to-ductile fabrics of the basement rocks and the Permian La Verde and Laguna Medina pluton from the Paileman Plutonic Complex (Vallés, 1978; Giacosa, 1993; Busteros et al., 1998; Giacosa and Paredes, 2001; González. et al., 2008b; García et al., 2014; González. et al., 2014b). The dyke swarm is parallel to the Permian orogenic axis postulated by Ramos (1984) and Llambías et al. (2002). The geochemical signature of the dykes relate them to a continental magmatic arc (González. et al., 2016). The intrusion and crystallization of the swarm have been proposed as Anisian (243.6 $\pm 1.7 \mathrm{Ma}$ U-Pb zircon age in González. et al., 2014b).

The previously mentioned units are cover by the Marifil Volcanic Complex (Malvicini and Llambías, 1974; Cortés, 1981). In the study area, the Marifil Volcanic Complex has a mesosilicic base (Monasa volcanic rocks) covered by a thick rhyolitic sequence (Franchi et al., 2001). There are sedimentary beds under and interlayered within the acidic volcanic sequence (Núñez et al., 1975; Zanettini, 1980; Cortés, 1981). The Marifil magmatism has been dated by several radiometric methods ( $\mathrm{Rb}-\mathrm{Sr}, \mathrm{K}-\mathrm{Ar}, \mathrm{Ar}-\mathrm{Ar}$ and $\mathrm{U}-\mathrm{Pb}$ ) and its age range between $221 \mathrm{Ma}$ and $153 \mathrm{Ma}$ (Fig. 1; Vallés, 1978; Cortés, 1981; Rapela and Pankhurst, 1993; Pankhurst et al., 1998, 2000; Féraud et al., 1999; Franchi et al., 2001; Riley et al., 2001). Because of its overall rhyolitic composition and Jurassic age, the Marifil Volcanic Complex has been included in the Chon Aike SLIP (Pankhurst et al., 1998, 2000).
The stratigraphic succession finishes with upper Cretaceous marine sediments and the Oligocene Somun Cura basalts.

\section{Mesosilicic rocks from arroyo ventana}

In the studied area, trachytic lava flows covering the Paileman Plutonic Complex were considered as the base of the Marifil Volcanic Complex (Giacosa, 1993; Franchi et al., 2001). These rocks appear in small and disperse outcrops in a $25 \mathrm{~km}$-long NNW-SSE trend from Los Berros to Arroyo Ventana (Fig. 2). They have been mentioned as the Monasa volcanic rocks by Franchi et al. (2001). The rocks are mostly trachytes, dark-grey to greenish dark even purplish dark colour. The rocks textures vary from porphyritic to aphyric and from massive to rich-vesicle (Fig. 3a-d). These textural variations have been interpreted as a superposition of multiple lava flows.

A decametric sequence of volcanogenic rocks (primary and reworked tuff) and epiclastic sandstones have been recognized covering the volcanic rocks. This sedimentary sequence plunges $10^{\circ}-20^{\circ}$ to the SE. Horizontal rhyodacitic pyroclastic flows cover the lava flows and the mentioned sedimentary rocks. Rhyolitic dykes cut the previously described sequence (Fig. 2). The volcanogenic rocks and the rhyolitic dykes also were considered as part of the Marifil Volcanic Complex (Giacosa, 1993; Busteros et al., 1998; Franchi et al., 2001).

\subsection{Petrography}

The trachytictic lava flows have a porphyritic texture whith phenocrysts of plagioclase, pyroxene and biotite in an aphanitic, dark grey groundmass (Fig. 3 e). In some cases, the presence of vesicles and amygdales indicate subaerial cooling (Fig. $3 \mathrm{f}$ ).

The phenocrysts are strongly altered; clay minerals and carbonate pseudomorphically replace the plagioclase crystals. The pyroxene crystals are completely replaced by carbonate and chlorite while the biotite crystals are altered to sericite and iron oxides. The groundmass is glassy (now devitrified to microspherulites) with acicular microlites oriented by flow.

These rocks show strongly altered xenoliths. The xenoliths have cumulate textures with cumulus olivine and intercumulus of oxides. The olivine crystals exhibit a pseudomorphic serpentinization (serpentine, bowlingite, chlorite, carbonate and oxides).

\subsection{Age}

In order to obtain U-Pb zircon age of the Monasa volcanic rocks, zircons were separated from a trachytic lava flow located at $41^{\circ} 38^{\prime}$ 56.15" S and 65 59' 59,7" W (Fig. 2).

The reduction of the sampled rock and concentration of zircons were performed in the Centro de Investigaciones Geológicas (UNLP-CONICET, Argentina). First, the sample was crushed and the disaggregated material was separated by granulometry using sieves. The fraction smaller than $180 \mu \mathrm{m}$ was used to concentrate heavy minerals by hydraulic methods. Then, these minerals were separated by magnetic susceptibility techniques using neodymium hand-magnet and Frantz. Finally, the zircons were separated over nonmagnetic fraction under binocular microscope.

The U-Pb analyses were carried out in the Centro de Pesquisas Geocronólogicas (CPGeo - Instituto de Instituto de Geociências - Universidade de São Paulo, Brasil). The zircons were set in an epoxy resin mount. The mount was polished and then vacuum-coated with high-purity gold in order to perform electron photomicrographs by cathodoluminescence $(\mathrm{CL})$ and secondary electrons (SE) with the Scanning electron microscope (SEM). After CL and SE images acquisition, the gold was removed 


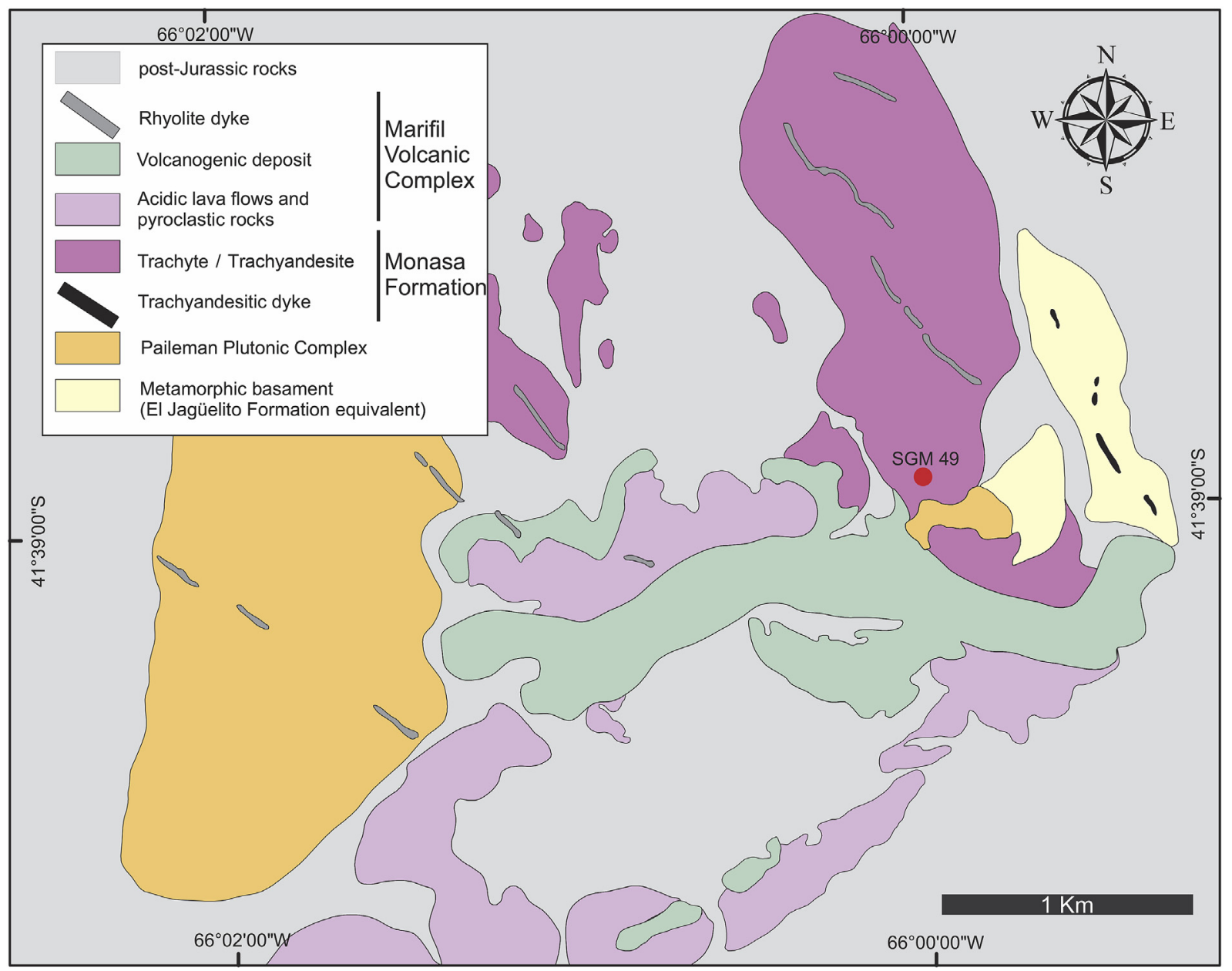

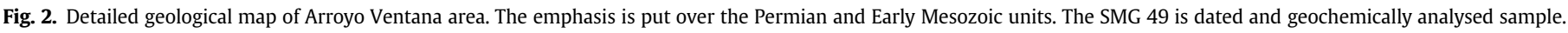

and the mount was polished and photographed under binocular microscope. The spots to be analysed were selected using all the previously obtained images considering the internal structure of the crystals and the fracturing degree of the crystals (McLaren et al., 1994).

$\mathrm{U}-\mathrm{Pb}$ analyses were executed using a Thermo-Fisher Neptune laser-ablation multi-collector inductively coupled plasma mass spectrometer (LA-MC-ICPMS) equipped with a 193 Photon laser system following the methodology applied by Sato et al. (2010). The laser spot used was $32 \mu \mathrm{m}$ in diameter. The U-Pb data were represented in Concordia and Tera-Wasserbug diagrams performed with the Isoplot/Ex software (Ludwig, 2008).

Ninety-three igneous crystals of zircon with euhedral prismatic habit were separated. Their aspect ratios range between 1:2 to $1: 4$ and the length of the major axis is variable between 100 and $250 \mu \mathrm{m}$. The crystals are mostly limpid with scarce fluid inclusions. In $\mathrm{CL}$ images, they show an oscillatory zoning structure typical of magmatic zircons.

Twenty-five $\mathrm{U}-\mathrm{Pb}$ analyses were performed in twenty-five crystals. The Th/U ratio of the crystals ranges between 0.984 and 2.755 (Fig. 4). Individual ages range between 236 and 255 Ma. Twenty-three results conform a cluster allowing to calculate a Concordia age of $247.22 \pm 0.46 \mathrm{Ma}(\mathrm{MSWD}=0.032$; Fig. 5 , table A.1 appendix A).

The oscillatory zoning structure and the Th/U ratio $(>0.1)$ of the analysed zircons are typical from magmatic crystals.

\subsection{Whole-rock geochemistry}

There are scarce geochemical data of the trachytic flows at the base of the Marifil Volcanic Complex. Six geochemical analyses have been published until now (Giacosa, 1993; Pankhurst and Rapela, 1995; Busteros et al., 1998). We provide one new geochemical data from the same sample analysed by the $\mathrm{U}-\mathrm{Pb}$ method (table A.2 appendix A).

Major and trace element concentrations were determined in $0.2 \mathrm{~g}$ of powder from the sample SGM 49 which was prepared by alkaline fusion with lithium borate, diluted with acid digestion and analysed in ICP-MS at ACME Analytical Laboratories S.A.

Using TAS diagram the sample has been chemically classified as a trachyte (Fig. 6a, q = 18.9; Le Maitre et al., 2002). It is below the Irvine and Baragar (1971) curve in the field of the subalkaline rocks (Fig. 6a).

The already published geochemical data of the mesosilicic lava flows have been included in the TAS diagram. The trachyandesitic dykes studied by González. et al. (2016) are similar in chemical composition and age, and have been compared with the mesosilicic rocks at base of the Marifil Volcanic Complex (Giacosa, 1993; González. et al., 2014b). The former samples from the basal rocks from the Marifil Volcanic Complex are chemically classified as basaltic andesites, andesites, basaltic trachyandesites and trachyandesites (Fig. 6a; Giacosa, 1993; Pankhurst and Rapela, 1995; Busteros et al., 1998). The scatter pattern of the samples in the TAS diagram may respond to different analytical methods or to the 


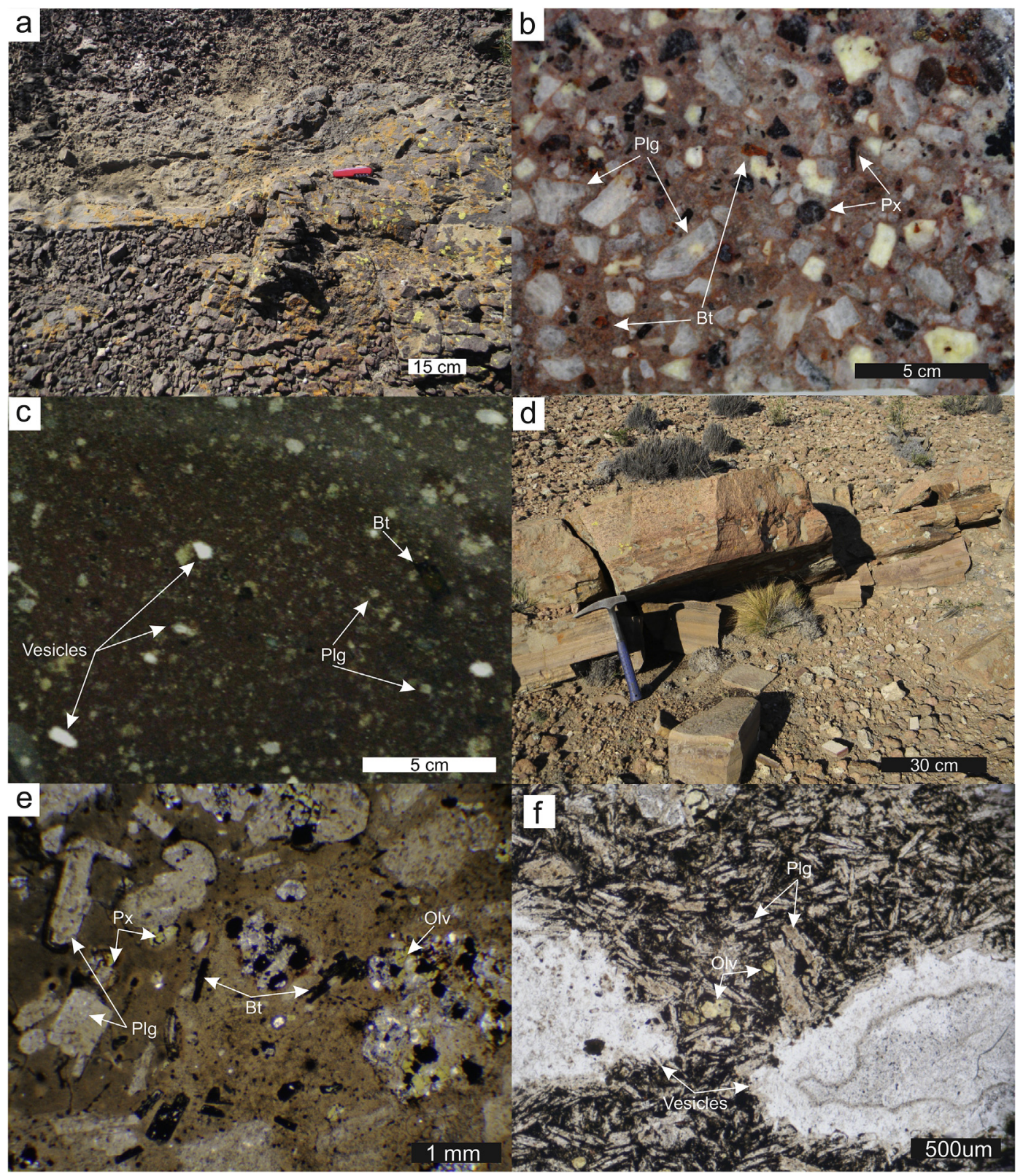

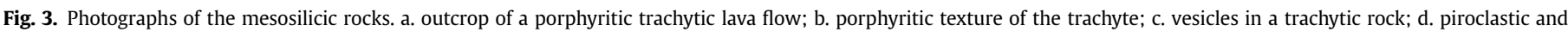

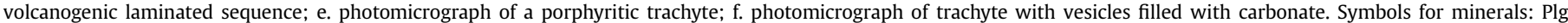
(plagioclase), Bt (biotite), Px (pyroxene), Olv (Olivine).

alteration degree of the samples.

Alumina saturation molar ratio (Shand, 1944) is 0.96 meanwhile the alkalinity index is 0.69 , indicating that the sample SGM49 is metaluminous and sub-alkaline.

Incompatible element variation pattern is shown in Fig. 6b (normalized to the primitive mantle after Sun and McDonough, 1989) The trachyte shows an inclined pattern (i.e., enrichment in Large Ion Lithofile Elements - LILE- relative to High Field Strength Elements -HFSE-) characterized by negative $\mathrm{Sr}, \mathrm{Nb}, \mathrm{P}$, and $\mathrm{Ti}$ anomalies (Fig. 6b). A relative enrichment in $\mathrm{Ba}, \mathrm{Rb}$ and $\mathrm{K}$ is also evident. The $(\mathrm{Rb} / \mathrm{Yb})_{\mathrm{N}}$ ratio is high, 132.065 .

The Rare Earth Elements (REE) concentrations have been illustrated in the chondrite-normalized diagram (Fig. 6c; chondrite normalized after Sun and McDonough, 1989). The REE distribution diagrams show an inclined pattern with a high Light REE content as opposed to a lower Heavy REE content. The ( $\mathrm{La} / \mathrm{Lu}) \mathrm{N}$ ratio is 13.28 . The sample exhibit a negative Eu anomaly $\left(\mathrm{Eu} / \mathrm{Eu}^{*}=0.62\right)$.

In the Gorton and Schandl (2000) tectonic discrimination diagram for mesosilicic rocks the sample SGM 49 plot on the line that separated the active magmatic arc and the within plate volcanic zone fields (Fig. 6d).

\section{Discussion and interpretation}

\subsection{Implications of the new data for the Triassic magmatism in} eastern North Patagonian Massif

The Triassic lava flows in Arroyo Ventana - Los Berros area are chemically trachytic. As the lava flows cover Permian granitoid (UPb SHRIMP in García et al., 2014) and are covered by Jurassic 


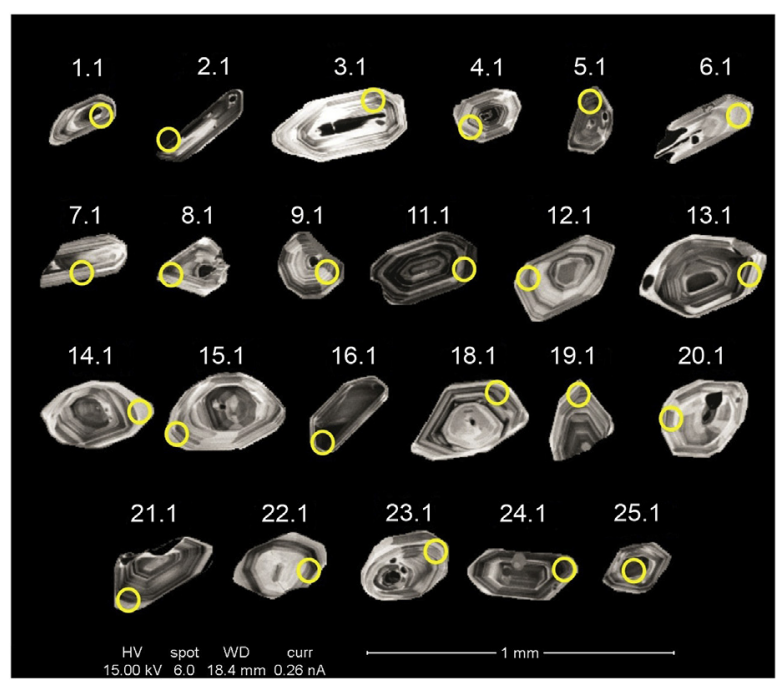

Fig. 4. Cathodoluminescence images of magmatic zircons of the sample SGM 49 analysed by LA-MC-ICPMS. The spot number is shown for each grain.

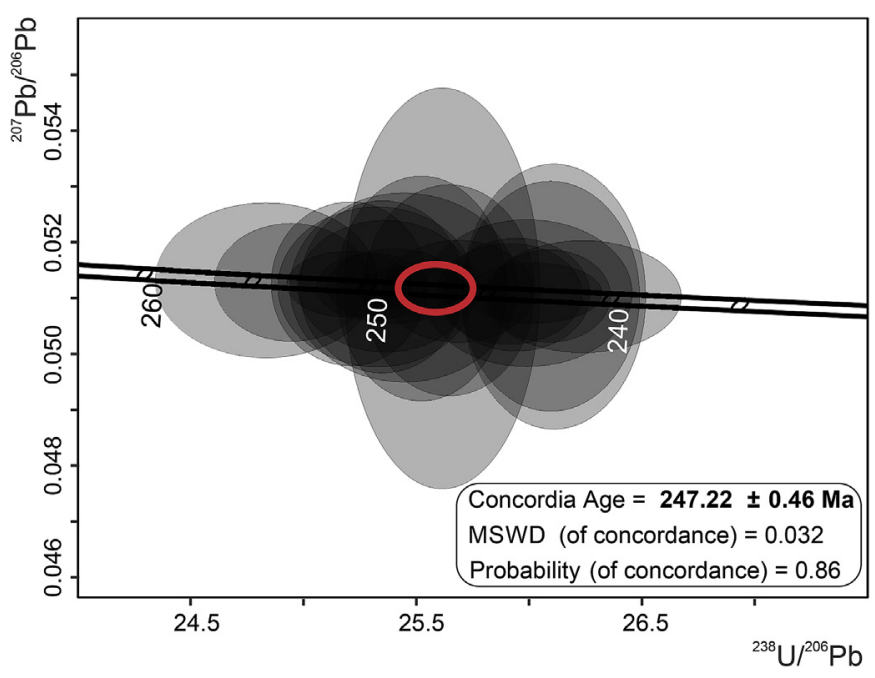

Fig. 5. U-Pb Tera - Wasserburg concordia diagram of LA-MC-ICPMS U-Pb zircon data

rhyodacitic volcanis rocks, the new $\mathrm{U}-\mathrm{Pb}$ zircon age of $247.22 \pm 0.46$ Ma could be considered close to the effusion and crystallization age of the lava flow.

As was previously mentioned, the Monasa volcanic rocks and the dyke swarm from the eastern North Patagonian Massif, characterized by González et al. (2014b, 2016), are similar in age and composition. As is shown in Fig. 6a-d, the presented geochemical data from the trachyte lava has a similar pattern to the trachyandesitic dykes from the swarm. The geochemical and age similarities in combination whit the geographic closeness might be interpreted as a genetic relation between the dykes and the lava flows. The dykes might be considered as the feeders of the volcanism.

\subsection{Correlation with other areas of the North Patagonian Massif}

The early Mesozoic volcanism has been registered in other areas of the North Patagonian Massif. We are going to summarize the Paleozoic - Mesozoic transition in four areas of the North Patagonian Massif in order to compare them with Arroyo Los Berros area (Fig. 7).
In Cerros del Ingeniero, Haller (1981) has described three units in the Paleozoic - Mesozoic transition. The La Irene granite is a subcircular equigranular body intruded by aplitic dykes. The granite is covered by ignimbrites of the Marifil Volcanic Complex and has been dated in $240 \pm 10 \mathrm{Ma}$ (K-Ar whole rock). The La Irene granite has been correlated with the Permian Paileman Plutonic Complex. Porphyritic pinkish dacites from the Cerros del Ingeniero Formation ( $237 \pm 10 \mathrm{Ma} \mathrm{K}-\mathrm{Ar}$ whole rock) are also covered by the Marifil Volcanic.

In the Valcheta area the Triassic - Early Jurassic Treneta Volcanic and Plutonic Complex overlay the Permian Navarrete Plutonic Complex (U-Pb zircon crystallization age of $281 \mathrm{Ma}$ in Pankhurst et al., 2006) and it is covered by the Jurassic Marifl Volcanic Complex (Núñez et al., 1975; Caminos, 1983, 2001). The Triassic Treneta volcanism contains andesitic and trachyandesitic lava flows as its older component laying directly over the basement or intercalated with volcaniclastic sediments. These rocks are dark to light grey with vesicles and are scarce in the sequence. A thick acidic volcanic and volcaniclastic sequence covered the older rocks and are intruded by younger acidic plutons from the same complex (Flores Granite - Rb-Sr age of $188 \pm 3$ in Pankhurst et al., 1993). The Treneta Volcanic and Plutonic Complex shows ages between 290 and $172 \mathrm{Ma}$ (K-Ar and Rb-Sr radiometric age in Caminos, 1983, 2001; Pankhurst et al., 1992, 1993). Because of its similarity with Los Menucos Complex, which contains Dicroidium flora (Artabe, 1985a, b), the Treneta vulcanism has been proposed as Middle Triassic (Caminos, 2001). The basal mesosilicic volcanism from Treneta Volcanic and Plutonic Complex has a comparable composition and similar stratigraphic position than the andesites from the Monasa Formation.

In the La Esperanza - Los Menucos area there are three magmatic units from Permian to Early Mesozoic, La Esperanza Plutonic Complex, Dos Lomas Volcanic - Plutonic Complex and Los Menucos Complex (Llambías and Rapela, 1984; Cucchi et al., 2001; Lema et al., 2008). The Dos Lomas Volcanic - Plutonic Complex comprise shallow emplacement granites intruded in lava flows and pyroclastic density currents. The plutonic rocks are the endmembers of the magmatic system and they are genetically related to their volcanic country rocks (Llambías and Rapela, 1984). The extrusive rocks overlay Permian granitoids from the La Esperanza Plutonic Complex (Llambías and Rapela, 1984; Pankhurst et al., 2006). The volcanic and pyroclastic rocks have been dated between 264 and $246 \mathrm{Ma}$ whereas the intrusive member is $250 \mathrm{Ma}$ (U-Pb SHRIMP zircon data in Pankhurst et al., 2006). Southwards, El Piche fault system separate the Dos Lomas Plutonic and Volcanic Complex from Los Menucos Complex (Giacosa et al., 2007). The field relation between these units has not been recognized but Los Menucos Complex has been assigned to the Middle to Late Triassic basis on Dicroidium Flora (Artabe, 1985a, b). Los Menucos Complex is a volcanic and volcaniclastic thick sequence of acidic rocks (Labudía and Bjerg, 2001). The volcaniclastic rocks include ash-fall deposits and volcanogenic deposits with scarce pyroclastic density currents, lava flows and domes. Vitrophyric domes and rhyolitic lavas were dated by Rb-Sr whole rock method between 215 and 222 Ma (Rapela et al., 1996).

As was proposed by Caminos (2001) there are clear similarities between Los Menucos Volcanic Complex and Treneta Volcanic and Plutonic Complex. We found that this similarity should include the Dos Lomas Volcanic - Plutonic Complex. We found that the discontinuity between the Permian granitoids and the Early Mesozoic mostly-volcanic cover could be used as a regional correlation surface. Based on this criterion Fig. 7 was constructed to clarify the similarities found between the previously described units with the Monasa Formation.

The Early Triassic magmatism found in the study area could be part of a major igneous event widespread all over the North 

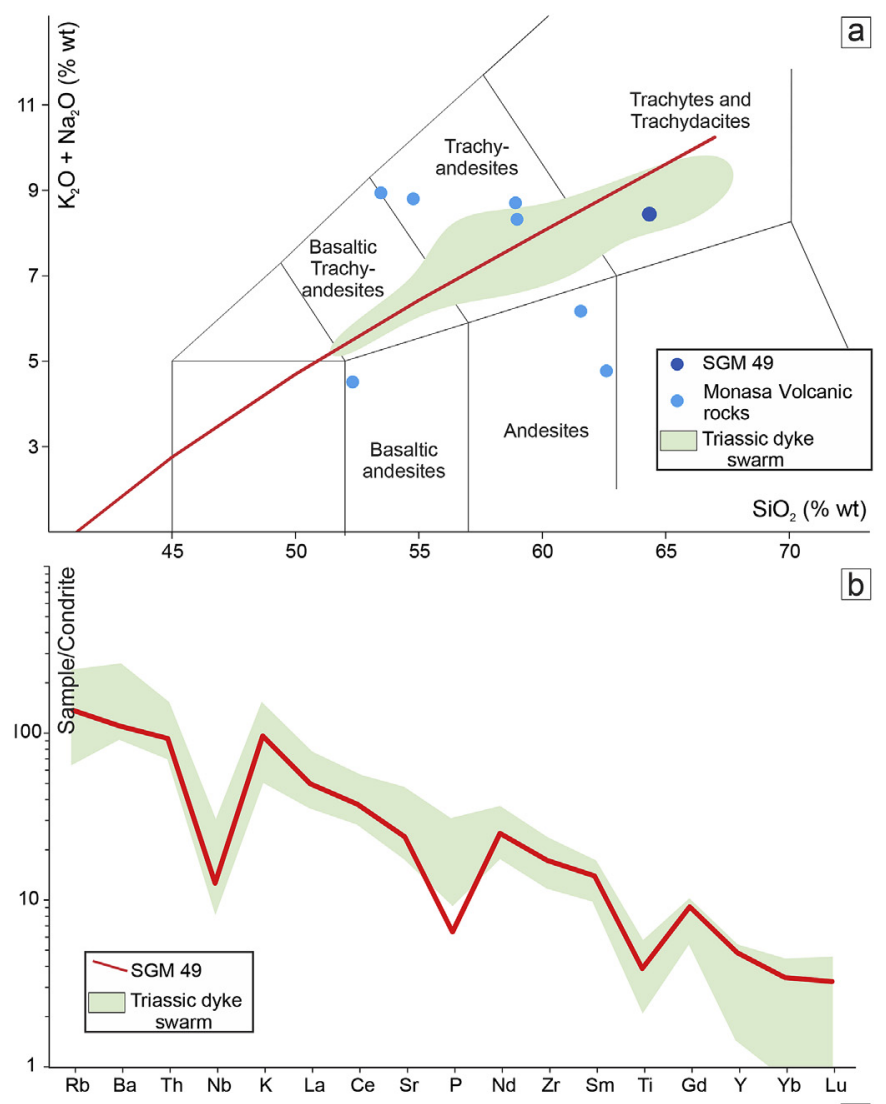

C

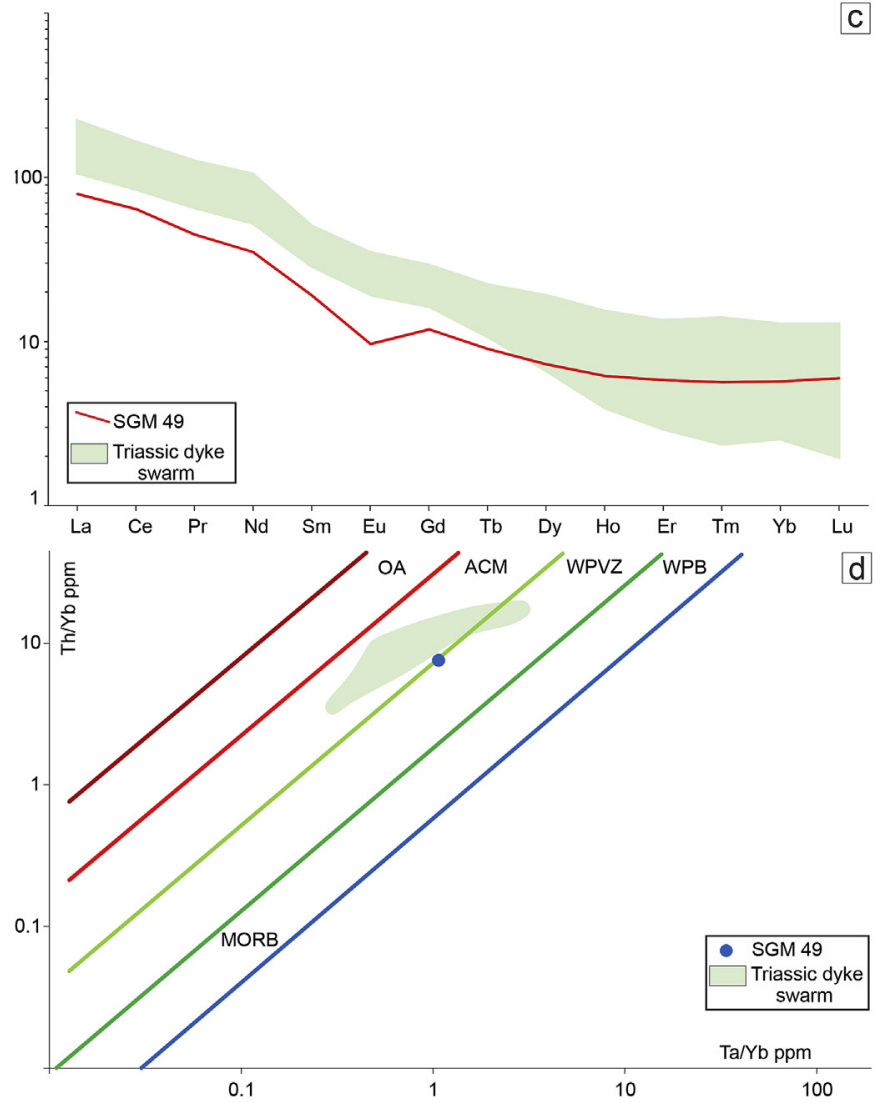

Fig. 6. Geochemistry diagrams for the analysed rock. a. TAS classification diagram (Le Maitre et al., 2002) showing the Irvine and Baragar (1971) curve. Previous analysis were taken from Giacosa (1993), Pankhurst and Rapela (1995), Busteros et al. (1998); b. incompatible element variation pattern normalized to the primitive mantle after Sun
Patagonian Massif. This magmatism is different in age and composition to the Jurassic rhyolitic Marifil Volcanic Complex. These two magmatic units represent different large-scale igneous events in the evolution of Patagonia and they should be consider separately. We consider the name Monasa Formation (Franchi et al., 2001) as the Early to Middle Triassic andesitic magmatic units in the Arroyo Ventana - Sierra Grande area (including the volcanic and subvolcanic products), temporally equivalent to the Cerro del Ingeniero Formation, the lower andesitic Treneta volcanic rocks and to the Dos Lomas Volcanic - Plutonic Complex. Further studies should be focus on the spatial and temporal extension of this unit. The presence of a Triassic sedimentary cover in the east of the North Patagonian Massif is plausible considering the epiclastic rocks covering the andesitic lava flows described in Section 3, comparable to Vera Formation from Los Menucos Volcanic Complex.

\subsection{Tectonic setting for the early Mesozoic magmatism}

Some local geology aspects could be related to major geotectonic processes allowing a geotectonic discrimination between the Triassic and the Jurassic magmatism.

As was mentioned in the previous sections, the Monasa Formation covers an erosive surface carved over Permian granites. These plutonic rocks were related to a magmatic arc associated with the Gondwanide orogen (Giacosa, 1993, 1994; Grecco et al., 1994; Busteros et al., 1998; García et al., 2014). The Permian plutons were uplifted and exposed to erosion in a $\mathrm{ca}$. $14 \mathrm{Ma}$ lapse of time, between their crystallization (as La Verde Pluton of $261 \mathrm{Ma}$ in García et al., 2014) and the eruption of the lavas from the Monasa Formation (247 Ma). The postorogenic extension associated to the emplacement of the dyke swarm (González et al., 2014b, 2016) could be the responsible for the exhumation of the Permian plutons.

The exhumation, caused by the postorogenic extension, could lead to partial melting of the lower lithosphere by adiabatic decompression (Gill, 2010; Winter 2014). Faults associated to the extension of the lithosphere could allow the magma ascension and emplacement. The ascending magma feed subvolcanic (dykes) and volcanic systems. Thus, the Triassic extensional tectonics might by responsible for the exhumation of the Permian plutons and the rise and emplacement of the Triassic magmatic systems.

The geochemical signature of the trachyte lava flow is similar to the dyke swarm from González et al. (2016) and reflects the inheritance of a continental magmatic-arc with transitional features to post-collisional or anorogenic magmas (Fig. 6d). These geochemical characteristics support the postorogenic extensional tectonics origin for the Triassic mesosilicic magmatism with a heritage from an active subduction zone.

The origin of the Jurassic rhyolitic plateau of the Marifil Volcanic Complex has been related to a mantel plume activity (Pankhurst et al., 1998, 2000; Riley et al., 2001). According to Pankhurst et al. (2000) the Marifil Volcanic Complex represents the first burst of volcanism in the Chon Aike Silicic Large Igenous Province (V1 between 178 and $188 \mathrm{Ma}$ ). The rhyolitic ignimbrites have within-plate affinities in the northeast Patagonia (Pankhurst et al., 2000). The large volume of rhyolitic magma erupted has been related to upper crustal magma chambers feeding large caldera volcanoes (Aragón et al., 1996; Pankhurst et al., 1998). The production of this large

and McDonough (1989); c. REE concentrations normalized to chondrite after Sun and McDonough (1989); d. tectonic discrimination diagram for mesosilicic rocks after Gorton and Schandl (2000); $\mathrm{OA}=$ oceanic arc, $\mathrm{ACM}=$ active magmatic arc, $\mathrm{WPVZ}=$ within-plate volcanic zone, $\mathrm{WPB}=$ within-plate basalt, $\mathrm{MORB}=$ mid ocean ridge basalt. 


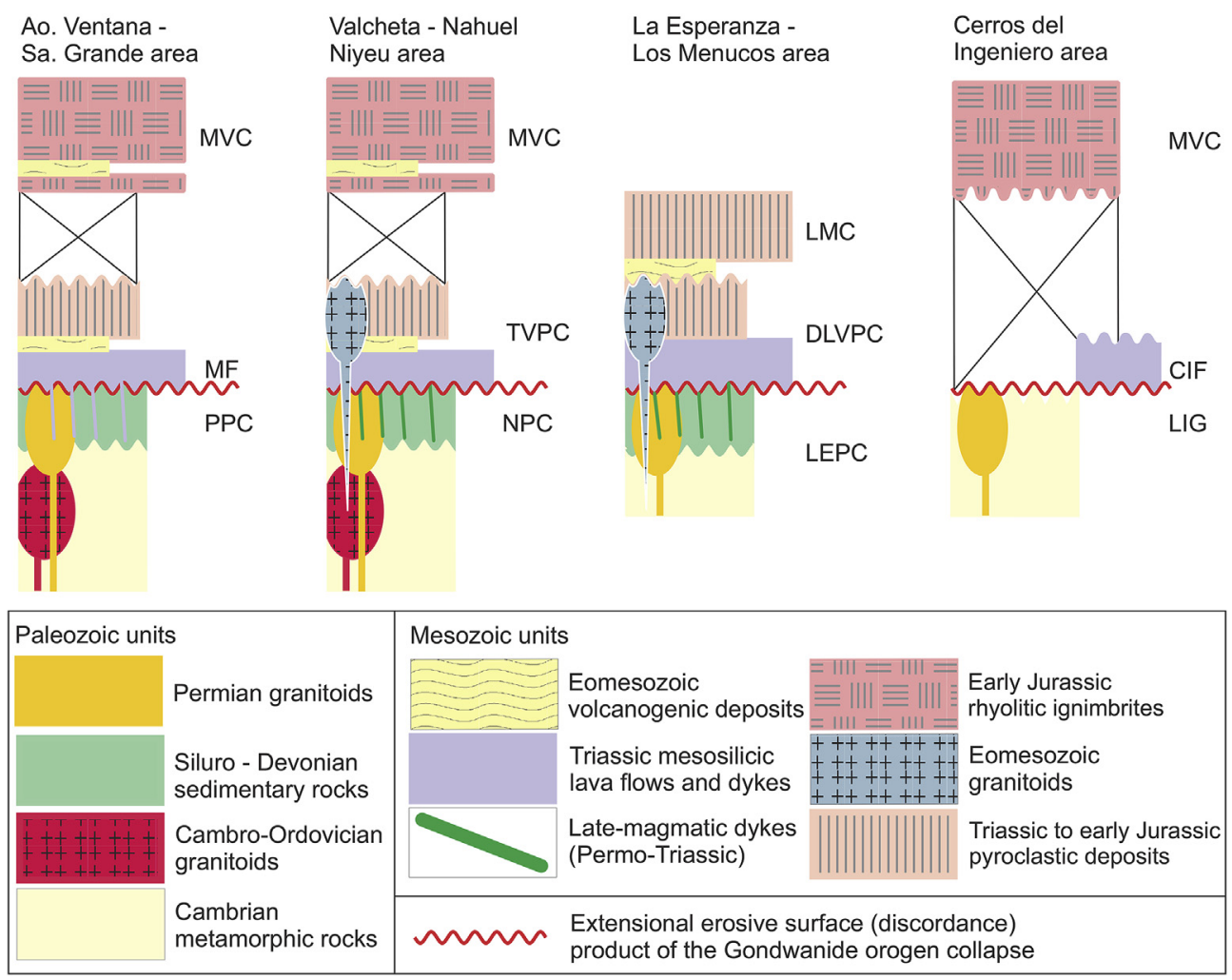

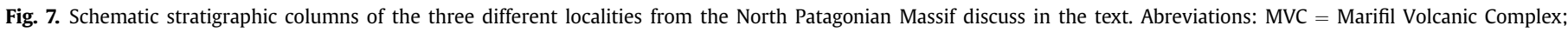

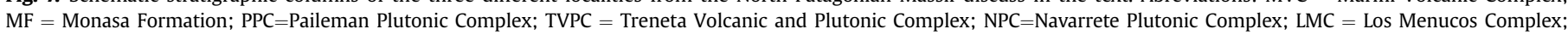
DLVPC $=$ Dos Lomas Volcanic - Plutonic Complex; CIF=Cerro del Ingeniero Formation; LIG = La Irene Granite.

amount of rhyolitic magma has been proposed as consequence of a multiple succession of crustal partial melting and fractional crystallization (Pankhurst and Rapela, 1995; Pankhurst et al., 1998). These magma reservoirs might occur as a consequence of the first extensional stages of Gondwana break-up and the emplacement of the Karoo - Ferrar basalt provinces (Pankhurst et al., 1998).

The geotectonic process proposed for the origin of the Triassic trachytic (mesosilicic) rocks is dissimilar to the one considered for the Jurassic acidic volcanism. The Triassic magmatism seems to be related to an extensional tectonic setting after the Gondwanide orogenesis. There are several possibilities to generate postorogenic extension in an active subduction zone. Changes in the subduction regimen (as delamination and/or slab break-off) could lead to extension by orogenic collapse (Bird, 1979; Liégeois and Black, 1987; Black and Liegeois, 1993; von Blanckenburg and Davies, 1995). Even a retreating orogen could produce an extensional tectonic setting (Cawood and Buchan, 2007; Cawood et al., 2009). Otherwise, the Jurassic magmatism has been related to a withinplate tectonic process. The extensional setting and the magma production for this rocks are related to the up-welling of the mantle in an incipient ocean, the Weddell Sea (Pankhurst et al., 2000; Riley et al., 2001).

\section{Conclusions}

According to the characteristics of the trachytic lavas described in the present work and the coeval magmatism widespread in the North Patagonian Massif, we conclude that:

1. Two different Early Mesozoic magmatic processes can be distinguished on petrological, geochemical and age basis in the
Eastern North Patagonia Massif: the Triassic postorogenic (postGondwanide orogen) and the Jurassic within-plate magmatism. They have a different composition and were originated by different geotectonic processes. The Monasa Formation are the Triassic, mesosilicic magmatic rocks that were considered until now the base of the Marifil Volcanic Complex in the northeaster Patagonia.

2. Because of its similarity (composition and age) with the dyke swarm described by González et al. (2014b, 2016) we consider that the Monasa formation is linked to the Gondwanic postorogenic extension.

3. There is a widespread Triassic magmatism in the North Patagonia Massif cropping out in different areas under different denominations: Cerro del Ingeniero Formation, Treneta Volcanic and Plutonic Complex, Dos Lomas Volcanic - Plutonic Complex and Monasa Formation. These units cover an erosive surface carved over Permian granites. We consider this erosive surface as a product of exhumation due to postorogenic extension during the collapse of the Gondwanide orogen.

\section{Acknowledgments}

We would like to express our sincere thanks to the people from Sierra Grande to Arroyo Ventana, all over the wide eastern part of Río Negro province, for allowing us the access to their lands and for their hospitality during our fieldwork. Fieldwork and laboratory tasks were possible with the financial contributions of the Universidad Nacional de La Plata, UNLP Project 11 / N 653, and Consejo Nacional de Investigaciones Científicas y Técnicas, PIP-CONICET 0119 and PIP-CONICET 324. 


\section{Appendix A. Supplementary data}

Supplementary data related to this article can be found at http:// dx.doi.org/10.1016/j.jsames.2017.02.007.

\section{References}

Aragón, E., Rodriguez, A.M.I., Benialgo, A., 1996. A calderas field at the Marifil Formation, new volcanogenic interpretation, Norpatagonian Massif, Argentina. J. S. Am. Earth Sci. 9, 321-328. http://dx.doi.org/10.1016/S0895-9811(96)00017-X.

Artabe, A.E., 1985a. Estudio sistemático de la tafoflora triásica de Los Menucos, provincia de Río Negro. Parte II. Cycadophyta, Ginkgophyta y Coniferophyta. Ameghiniana 22, 159-180.

Artabe, A.E., 1985b. Estudio sistemático de la tafoflora triásica de Los Menucos, provincia de Río Negro. Parte I. Sphenophyta, Filicophyta, Pteridospermophyta. Ameghiniana 22, 3-22.

Bird, P., 1979. Continental delamination and the Colorado plateau. J. Geophys. Res. Solid Earth 84, 7561-7571.

Black, R., Liegeois, J.P., 1993. Cratons, mobile belts, alkaline rocks and continental lithospheric mantle: the Pan-African testimony. J. Geol. Soc. 150, 89-98.

Busteros, A., Giacosa, R., Lema, H., 1998. Hoja Geológica 4166-IV, Sierra Grande, Provincia de Río Negro. Servicio Geológico Minero Argentino, Buenos Aires, 75 pp.

Caminos, R., 1983. Descripción geológica de las Hojas 39g. Cerro Tapiluke y 39h, Chipauquil, provincia de Río Negro. Servicio Geológico Nacional, Buenos Aires.

Caminos, R., 2001. Hoja Geológica 4166-I, Valcheta, provincia de Río Negro. Instituto de Geología y Recursos Minerales - Servicio Geológico Minero Argentino, Buenos Aires, 73 pp.

Cawood, P.A., Buchan, C., 2007. Linking accretionary orogenesis with supercontinent assembly. Earth-Science Rev. 82, 217-256.

Cawood, P.A., Kröner, A., Collins, W.J., Kusky, T.M., Mooney, W.D., Windley, B.F., 2009. Special Publications. Accretionary Orogens through Earth History, vol. 318. Geological Society, London, pp. 1-36.

Cortés, J., 1981. El substrato precretácico del extremo noreste de la Provincia del Chubut. Rev. Asoc. Geol. Argent. 36, 217-235.

Cucchi, R., Busteros, A., Lema, H., 2001. Hoja Geológica 4169-II, Los Menucos, provincia de Río Negro. Instituto de Geología y Recursos Minerales - Servicio Geológico Minero Argentino, Buenos Aires, 67 pp.

de Alba, E., 1964. Descripción Geológica de la hoja 41j Sierra Grande. Dirección Nacional de Geología y Minería, Buenos Aires, 67 pp.

Féraud, G., Alric, V., Fornari, M., Bertrand, H., Haller, M., 1999. ${ }^{40} \mathrm{Ar} /{ }^{39} \mathrm{Ar}$ dating of the Jurassic volcanic province of Patagonia: migrating magmatism related to Gondwana break-up and subduction. Earth Planet. Sci. Lett. 172, 83-96. http:// dx.doi.org/10.1016/S0012-821X(99)00190-9.

Franchi, M., Ardolino, A., Remesal, M., 2001. Hoja Geológica 4166 III, Cona Niyeu, provincia de Río Negro. Instituto de Geología y Recursos Minerales Servicio Geológico Minero Argentino, Buenos Aires, 83 pp.

García, V.A., González, S.N., Tassinari, C.C.G., Sato, K., Sato, A.M., González, P.D., Varela, R., 2014. Geoquímica y geocronología del Plutón La Verde, Macizo Nordpatagónico, provincia de Río Negro. Córdoba, Actas. In: Martino, R.D., et al. (Eds.), XIX Congreso Geológico Argentino, pp. 373-374.

Genovese, S., 1995. Geología y geocronología del área de la mina La Leona, departamento San Antonio, provincia de Río Negro. Trabajo Final de Licenciatura, Universidad Nacional de Buenos Aires (unpublished), 76 pp. Ciudad Autonoma de Buenos Aires.

Giacosa, R., 1987. Caracterización de un sector del basamento metamórfico-migmatítico en el extremo suroriental del Macizo Norpatagónico. San Miguel de Tucumán, Actas. In: X Congreso Geológico Argentino. Provincia de Río Negro, Argentina, pp. 51-54.

Giacosa, R., 1993. El ciclo eruptivo gondwánico en el area de Sierra Pailemán, Macizo Nordpatagónico, Argentina. Mendoza, Actas. In: XII Congreso Geológico Argentino y 2 Congreso de Exploración de hidrocarburos, pp. 113-119.

Giacosa, R., 1994. Geología y petrología de las rocas pre-Cretácicas del área arroyo Salado-arroyo Tembrao, sector oriental del Macizo Norpatagónico, Río Negro. Ph. D. thesis. Universidad Nacional de la Patagonia San Juan Bosco, Comodoro Rivadavia, 200p.

Giacosa, R., 2001. Zonas de cizalla frágil-dúctil neopaleozoicas en el nordeste de la Patagonia. Rev. Asoc. Geol. Argent. 56, 131-140.

Giacosa, R., Paredes, J., 2001. Estructura de las metamorfitas del Paleozoico temprano en el Arroyo. Salado. Macizo Nordpatagónico, Río Negro. Rev. Asoc. Geol. Argent. 56, 141-149.

Giacosa, R., Lema, H., Busteros, A., Zubia, M., Cucchi, R., Di Tommaso, I., 2007. Estructura del Triásico de la región norte del Macizo Nordpatagónico $\left(40^{\circ}-41^{\circ} \mathrm{S}\right.$, $67^{\circ} 30^{\prime}-69^{\circ} 45^{\prime}$ ) Río Negro. Rev. Asoc. Geol. Argent. 62, 355-365.

Gill, R., 2010. Igneous Rocks and Processes: a Practical Guide. John Wiley \& Sons, Chichester, UK, 428 pp.

González, P.D., Poiré, D., Varela, R., 2002. Hallazgo de trazas fósiles en la Formación El Jagüelito y su relación con la edad de las metasedimentitas, Macizo Nordpatagónico Oriental, provincia de Río Negro. Rev. Asoc. Geol. Argent. 57, 35-44.

González, P.D., Varela, R., Sato, A.M., Campos, H., Greco, G., Naipauer, M., Llambías, E., García, V., 2008a. Metamorfismo regional Ordovícico y estructura de la Ectinita El Jagüelito al SO de Sierra Grande, Río Negro. San Salvador de Jujuy, Actas. In: XVII Congreso Geológico Argentino, pp. 849-850.
González, P.D., Varela, R., Sato, A.M., Llambías, E.J., González, S.N., 2008b. Dos fajas estructurales distintas en el Complejo Mina Gonzalito, Río Negro. San Salvador de Jujuy, Actas. In: XVII Congreso Geológico Argentino, pp. 847-848.

González, P.D., Greco, G., Varela, R., Naipauer, M., Sato, A.M., Llambías, E., García, V. Campos, H., 2011a. Patrón metamórfico invertido en la Formación El Jagüelito de la Herradura del Salado, Basamento Norpatagónico, Río Negro. Neuquén, Actas en CD. In: Leanza, H., et al. (Eds.), XVIII Congreso Geológico Argentino, pp. $85-86$.

González, P.D., Tortello, M.F., Damborenea, S.E., 2011b. Early cambrian archaeocyathan limestone blocks in low-grade meta-conglomerate from el jagueelito formation (Sierra Grande, Río Negro, Argentina). Geol. Acta 9, 159-173.

González, P.D., Sato, A.M., Varela, R., Naipauer, M., Llambías, E.J., Castro Dorado, A., 2013. Volcanismo de arco asociado a la Formación El Jagüelito, Sierra Grande, Río Negro. San Luis, Libro de actas. In: $2^{\circ}$ Simposio Petrología Ígnea y Metalogénesis Asociada, pp. 39-40.

González, P.D., Sato, A.M., Varela, R., Greco, G.A., Naipauer, M., Llambías, E.J., Basei, M.A.S., 2014. Metamorfismo y estructura interna de la Formación E Jagüelito en el Arroyo Salado inferior, Macizo Norpatagónico, Río Negro. Córdoba, Actas en CD. In: Martino, R.D., et al. (Eds.), XIX Congreso Geológico Argentino, pp. 381-382.

González, S.N., Greco, G.A., González, P.D., Sato, A.M., Llambías, E.J., Varela, R. Basei, M.A.S., 2014. Geología, petrografía y edad U-Pb de un enjambre longitudinal NO-SE de diques del macizo nordpatagónico oriental, Río negro. Rev. Asoc. Geol. Argent. 71, 174-183.

González, S.N., Greco, G.A., González, P.D., Sato, A.M., Llambías, E.J., Varela, R., 2016. Geochemistry of a triassic dyke swarm in the North Patagonian Massif, Argentina. Implications for a postorogenic event of the Permian Gondwanide orogeny. J. S. Am. Earth Sci. 70, 69-82. http://dx.doi.org/10.1016/j.jsames.2016. 04.009.

Gorton, M.P., Schandl, E.S., 2000. From continents to island arcs: a geochemical index of tectonic setting for arc-related and within-plate felsic to intermediate volcanic rocks. Can. Mineral. 38, 1065-1073. http://dx.doi.org/10.2113/ gscanmin.38.5.1065.

Grecco, L.E., Gregori, D.A., 2011. Geoquímica y geocronología del Complejo Plutónico Paileman, Comarca Nordpatagónica, provincia de Río Negro. Neuquén, Actas en CD. In: Leanza, H., et al. (Eds.), XVIII Congreso Geológico Argentino, pp. 91-92.

Grecco, L., Gregori, D., Rapela, C., Pankhurst, R., Labudía, C., 1994. Peraluminous granites in the Northeastern sector of the North Patagonian Massif. Concepción Actas. In: $7^{\circ}$ Congreso Geológico Chileno, pp. 1354-1359.

Greco, G.A., González, S.N., Sato, A.M., González, P.D., Llambías, E.J., Basei, M.A.S, 2014. Nueva datación en circones detríticos para el Complejo Mina Gonzalito, Provincia de Río Negro. Córdoba, Actas en CD. In: Martino, R.D., et al. (Eds.), XIX Congreso Geológico Argentino, pp. 1454-1455.

Greco, G.A., González, P.D., González, S.N., Sato, A.M., Basei, M.A.S., Tassinari, C.C.G. Sato, K., Varela, R., Llambías, E.J., 2015. Geology, structure and age of the nahuel niyeu formation in the Aguada Cecilio area, North Patagonian Massif, Argentina. J. S. Am. Earth Sci. 62, 12-32. http://dx.doi.org/10.1016/j.jsames.2015.04.005.

Haller, M., 1981. Descripción geológica de la Hoja 43 h, Puerto Madryn, provincia de Chubut. Servicio Geológico Nacional, Buenos Aires.

Irvine, T.N., Baragar, W.R.A., 1971. A guide to the chemical classification of the Common volcanic rocks. Can. J. Earth Sci. 8, 523-548. http://dx.doi.org/10.1139/ e71-055.

Japas, M.S., 2001. Modelo cinemático neopaleozoico para el sector nororiental del Macizo Norpatagónico, Argentina. J. Iber. Geol. 27, 91-122.

Labudía, C., Bjerg, E., 2001. El Grupo Los Menucos: redefinición estratigráfica del Triásico superior del Macizo Nordpatagónico. Rev. Asoc. Geol. Argent. 56, 404-407.

Le Maitre, R.W., Streckeisen, A., Zanettin, B., Le Bas, M., Bonin, B., Bateman, P., 2002 Igneous rocks: a classification and glossary of terms: recommendations of the international union of geological sciences subcommission on the systematics of igneous rocks. Cambridge University Press.

Lema, H., Busteros, A., Giacosa, R., Cucchi, R., 2008. Geología del Complejo Volcánico Los Menucos en el área tipo-Río Negro. Rev. Asoc. Geol. Argent. 63, 3-13.

Liégeois, J.P., Black, R., 1987. Special Publications. Alkaline magmatism subsequent to collision in the Pan-African belt of the Adrar des Iforas (Mali), vol. 30. Geological Society, London, pp. 381-401.

Lizuaín, A., Ragona, A., Folguera, A., 1995. Mapa Geológico de la Provincia de Chubut República Argentina. Secretaria de Minería. Dirección Nacional del Servicio Geológico, Buenos Aires.

Llambías, E.J., Rapela, C.W., 1984. Geología de los complejos eruptivos de La Esperanza, provincia de Río Negro. Rev. Asoc. Geol. Argent. 39, 220-243.

Llambías, E.J., Sato, A.M., 2011. Ciclo Gondwanico: la provincia magmatica Choiyoi en Neuquen. In: Leanza, H., Arregui, C., Carbone, O., Danieli, J., Vallés, J. (Eds.) Geología y recursos naturales de la provincia del Neuquén. Asociación Geológica Argentina, Buenos Aires, pp. 53-62.

Llambías, E.J., Varela, R. Basei, M., Sato, A.M., 2002. Deformación y metamorfismo Neopaleozoico en Yaminué, Macizo Norpatagónico (40 50'S, 67 40'W): su relación con la Fase Orogénica San Rafael y el arco de los Gondwánides. E Calafate, Actas. In: Cabaleri, N.G., Cingolani, C.A. (Eds.), XV Congreso Geológico Argentino, pp. 123-128.

Ludwig, K.R., 2008. User's Manual for Isoplot 3.6: a Geochronological Toolkit for Microsoft Excel, vol. 4. Berkeley Geochronology Center Special Publication, p. 77.

Malvicini, L., Llambías, E., 1974. Geología y génesis del depósito de manganeso Arroyo Verde, provincia del Chubut. Córdoba, Actas. In: V Congreso Geológico 
Argentino, pp. 185-202.

McLaren, A.C., Gerald, J.D.F., Williams, I.S., 1994. The microstructure of zircon and its influence on the age determination from $\mathrm{Pb} / \mathrm{U}$ isotopic ratios measured by ion microprobe. Geochim. Cosmochim. Acta 58, 993-1005. http://dx.doi.org/10 1016/0016-7037(94)90521-5.

Naipauer, M., Sato, A.M., González, P.D., Chemale Jr., F., Varela, R., Llambías, E., Greco, G., Dantas, E., 2010. Eopaleozoic Patagonia-east Antartica connection: fossil and U-Pb evidence from el Jagüelito Formation. Brasilia, Short Paper Volume. In: 7th South American Symposium on Isotope Geology, pp. 602-605.

Núñez, E., Bachmann, E.W., de, R.I., Britos, A., Franchi, M., Lizuaín, A., Sepúlveda, E., 1975. Rasgos geológicos del sector oriental del Macizo Somuncura, provincia de Río Negro, República Argentina. Buenos Aires, Actas. In: $2^{\circ}$ Congreso Iberoamericano de Geología Económica, pp. 247-266.

Pankhurst, R.J., Rapela, C.W., 1995. Production of Jurassic rhyolite by anatexis of the lower crust of Patagonia. Earth Planet. Sci. Lett. 134, 23-36. http://dx.doi.org/10. 1016/0012-821X(95)00103-J.

Pankhurst, R.J., Rapela, C.W., Caminos, R., Llambias, E., Parica, C., 1992. A revised age for the granites of the central somuncura Batholith, North Patagonian Massif J. S. Am. Earth Sci. 5, 321-325. http://dx.doi.org/10.1016/0895-9811(92)90029$\mathrm{X}$.

Pankhurst, R.J., Rapela, C.W., Caminos, R., 1993. Problemas geocronológicos de los granitoides gondwánicos de Nahuel Niyeu, Macizo Norpatagónico. Mendoza Actas. In: XII Congreso Geológico Argentino y Segundo Congreso de Exploración de hidrocarburos, pp. 99-114.

Pankhurst, R.J., Leat, P.T., Sruoga, P., Rapela, C.W., Márquez, M., Storey, B.C. Riley, T.R., 1998. The Chon Aike province of Patagonia and related rocks in West Antarctica: a silicic large igneous province. J. Volcanol. Geotherm. Res. 81, 113-136. http://dx.doi.org/10.1016/S0377-0273(97)00070-X.

Pankhurst, R.J., Riley, T.R., Fanning, C.M., Kelley, S.P., 2000. Episodic silicic volcanism in Patagonia and the Antarctic Peninsula: Chronology of magmatism associated with the break-up of Gondwana. J. Petrol. 41, 605-625. http://dx.doi.org/10. 1093/petrology/41.5.605.

Pankhurst, R.J., Rapela, C.W., Fanning, C.M., Márquez, M., 2006. Gondwanide continental collision and the origin of Patagonia. Earth-Sci. Rev. 76, 235-257. http://dx.doi.org/10.1016/j.earscirev.2006.02.001.

Ramos, V.A., 1975. Geología del sector oriental del Macizo Nordpatagónico entre Aguada Capitán y la Mina Gonzalito, provincia de Río Negro. Rev. Asoc. Geol. Argent. 30, 274-285.

Ramos, V.A., 1984. Patagonia: un continente paleozoico a la deriva. Actas. In: IX Congreso Geológico Argentino San Carlos de Bariloche, pp. 311-325.

Rapela, C.W.. Llambías, E.J., 1985. Evolución magmática y relaciones regionales de los complejos eruptivos de La Esperanza, provincia de Río Negro. Rev. Asoc. Geol. Argent. 15, 4-25.

Rapela, C.W., Pankhurst, R.J., 1993. El volcanismo riolítico del noreste de la Patagonia: un evento meso-jurásico de corta duración y origen profundo. Mendoza, Actas. In: XII Congreso Geológico Argentino y 2 Congreso de Exploración de Hidrocarburos, pp. 179-188.

Rapela, C.W., Pankhurst, R.J., Llambías, E.J., Labudía, C., Artabe, A., 1996. “Gondwana” magmatism of Patagonia: inner Cordilleran calc-alkaline batholiths and bimodal volcanic provinces. St Malo, France, Extended abstracts. In: 3rd. International Symposium on Andean Geodynamics, pp. 791-794.

Riley, T.R., Leat, P.T., Pankhurst, R.J., Harris, C., 2001. Origins of large volume rhyolitic volcanism in the Antarctic Peninsula and Patagonia by crustal melting. J. Petrol. 42, 1043-1065. http://dx.doi.org/10.1093/petrology/42.6.1043.

Sato, A.M., Llambías, E.J., Basei, M.A.S., Castro, C.E., 2015. Three stages in the Late Paleozoic to Triassic magmatism of southwestern Gondwana, and the relationships with the volcanogenic events in coeval basins. J. S. Am. Earth Sci. 63, 48-69. http://dx.doi.org/10.1016/j.jsames.2015.07.005.

Sato, K., Basei, M.A.S., Ferreira, C.M., Vlach, S.R.F., Ivanuch, W., Siga Jr., O., T, O.A., 2010. In situ U-Th-Pb isotopic analyses by Excimer laser ablation/ICP-MS on Brazilian xenotime megacrystal: first U-Pb results at CPGeo-IG-USP. Brasilia, Abstracts in CD. In: 7th South American Symposium on Isotope Geology.

Eruptive Rocks. By Shand S. J. Second Edition, pp. xvi +444 , with 3 plates and 47 text-figures. London: Murby; and New York: Wiley, 1943. Price 25s. Geol. Mag. 81 (3), 1944, 137-138. http://dx.doi.org/10.1017/S0016756800075026.

Sun, S.S., McDonough, W.F., 1989. Special Publications. Chemical and Isotopic Systematics of Oceanic Basalts: Implications for Mantle Composition and Processes, vol. 42. Geological Society of London, pp. 313-345. http://dx.doi.org/10. 1144/GSL.SP.1989.042.01.19.

Uliana, M., Biddle, K., Phelps, D., Gust, D., 1985. Significado del vulcanismo y extensión mesojurásicos en el extremo meridional de Sudamérica. Rev. Asoc. Geol. Argent. 40, 231-253.

Vallés, J., 1978. Los yacimientos de plomo "María Teresa” y “Tres Marías”, ejemplos de metalogénesis mesozoica en el Macizo Norpatagónico, Provincia de Río Negro. Neuquén, Actas. In: VIII Congreso Geológico Argentino, pp. 71-78.

Varela, R., Basei, M., González, P., Sato, A., Sato, K., 2008. Granitoides Famatinianos y Gondwánicos en Sierra Grande. Nuevas edades radimétricas método U-Pb. San Salvador de Jujuy, Actas. In: XVII Congreso Geológico Argentino, pp. 914-915.

Varela, R., González, P.D., Basei, M.A.S., Sato, K., Sato, A.M., Naipauer, M., García, V.A. González, S.N., Greco, G., 2011. Edad del Complejo Mina Gonzalito: revisión y nuevos datos. Neuquén, Actas en CD. In: Leanza, H., et al. (Eds.), XVIII Congreso Geológico Argentino, pp. 127-128.

von Blanckenburg, F., Davies, J.H., 1995. Slab breakoff: a model for syncollisional magmatism and tectonics in the Alps. Tectonics 14, 120-131.

von Gosen, W., 2002. Polyphase structural evolution in the northeastern segment of the North Patagonian Massif (southern Argentina). J. S. Am. Earth Sci. 15, 591-623. http://dx.doi.org/10.1016/S0895-9811(02)00111-6.

von Gosen, W., 2009. Stages of Late Palaeozoic deformation and intrusive activity in the western part of the North Patagonian Massif (southern Argentina) and their geotectonic implications. Geol. Mag. 146, 48-71. http://dx.doi.org/10.1017/ S0016756808005311.

Winter, J.D., 2014. Principles of Igneous and Metamorphic Petrology, seond ed. Pearson.

Zanettini, J., 1980. Sedimentitas triásicas al sur de Sierra Grande (provincias de Río Negro y Chubut). Rev. Asoc. Geol. Argent. 35, 301-307. 